\title{
Cloning of a Candida albicans peptide transport gene
}

\author{
Munira A. Basrai, ${ }^{1} \dagger$ Mark A. Lubkowitz, ${ }^{1}$ Jack R. Perry, ${ }^{1}$ David Miller, ${ }^{1}$ \\ Eduardo Krainer, ${ }^{2}$ Fred Naider ${ }^{2}$ and Jeffrey M. Becker ${ }^{1}$
}

Author for correspondence: Jeffrey M. Becker. Tel: +1 615974 3006. Fax: +1 615974 4007; e-mail: IN\%“JBECKER@UTKVX.UTK.EDU”

1 Department of Microbiology and Program in Cellular, Molecular, and Developmental Biology, University of Tennessee, Knoxville, TN 37996-0845, USA

2 Department of Chemistry, College of Staten Island, City University of New York, Staten Island, New York 10301, USA
A Candida albicans peptide transport gene, CaPTR2, was cloned from a C. albicans genomic library by functional complementation of a peptide transport deficient mutant (strain ptr2-2) of Saccharomyces cerevisiae. CaPTR2 restored peptide transport to transformants as determined by uptake of radiolabelled dileucine, growth on dipeptides as sources of required amino acids, and restoration of growth inhibition by toxic peptides. Plasmid curing experiments demonstrated that the peptide transport phenotype was plasmid borne. CaPTR2 was localized to chromosome $R$ of $C$. albicans by contour-clamped homologous electric field gel chromosome blots. Deletion subclones and frameshift mutagenesis were used to narrow the peptide transport complementing region to a 5.1 kb DNA fragment. DNA sequencing of the complementing region identified an ORF of 1869 bp containing an 84 nucleotide intron. The deduced amino acid sequence predicts a protein of 70 kDa consisting of 623 amino acids with 12 hydrophobic segments. A high level of identity was found between the predicted protein and peptide transport proteins of S. cerevisiae and Arabidopsis thaliana. This study represents the first steps in the genetic characterization of peptide transport in C. albicans and initiates a molecular approach for the study of drug delivery against this pathogen.

Keywords: Candida albicans, peptide transport, Saccharomyces cerevisiae

\section{INTRODUCTION}

Studies from our laboratory and several others have characterized the peptide transport systems of Candida albicans and Saccharomyces cerevisiae (for reviews see Becker \& Naider, 1980; Naider \& Becker, 1987). Results from these studies suggested that both yeasts contain peptide permeases with structural requirements that differ from those of bacterial and mammalian peptide permeases (for reviews see Matthews, 1991; Payne, 1980). Though yeasts show optimal growth on peptides containing hydrophobic residues, they lack strict specificity, as indicated by their ability to transport modified peptides (Becker \& Naider, 1995). Peptide transport systems in yeasts are

\footnotetext{
†Present address: Department of Molecular Biology and Genetics, Johns Hopkins University, School of Medicine, Baltimore, MD 21205-0831, USA.

Abbreviations: Ala-Eth, alanyl-ethionine; RFLP, restriction fragment length polymorphism.

The GenBank accession number for the nucleotide sequence reported in this paper is U0978!.
}

regulated by nitrogen metabolism (Becker \& Naider, 1995), and are induced by the addition of micromolar amounts of certain amino acids (Basrai et al., 1992; Island et al., 1991).

In an effort to define peptide transport at the genetic level, $S$. cerevisiae strains resistant to the growth-inhibitory effects of the dipeptide alanyl-ethionine (Ala-Eth) were isolated (Island et al., 1991). These strains defined three complementation groups suggesting that peptide transport in $S$. cerevisiae is mediated by at least three genes, PTR1, PTR 2 and PTR 3 (Peptide TRansport). Mutations in PTR1 and PTR2 genes make the cells peptidetransport-deficient, whereas mutations in the $P T R 3$ gene result in an intermediate phenotype characterized by lowlevel transport of radiolabelled dipeptides. We have cloned and characterized the $S$. cerevisiae PTR1 (Alagramam et al., 1995) and PTR2 (Perry et al., 1994) genes which have ORFs of 5850 and $1803 \mathrm{bp}$, respectively. The deduced amino acid sequence of the $S$. cerevisiae $\operatorname{Ptr} 2 \mathrm{p}$ suggests a membrane protein with 12 transmembrane domains. PTR1 was found to be identical to $S$. cerevisiae 
UBR 1, the recognition component of the $\mathrm{N}$-end rule pathway which is a ubiquitin-dependent protein-degradation system (Alagramam et al., 1995; Bartel et al., 1990). Our working hypothesis is that PTR2 encodes the structural component of the peptide transport system while PTR1/UBR1 is responsible for regulation.

Current evidence, though not conclusive, suggests the presence of at least two peptide permeases in C. albicans. One of the systems mediates transport of di- and tripeptides, whilst the other transports tri- and oligopeptides (Becker \& Naider, 1995). A definitive characterization of the number and role of peptide permeases in $C$. albicans and their regulation will require combined genetic and biochemical approaches. Cloning of the genes involved in peptide transport in C. albicans will enable the comparative analysis of the structure and physiological role of membrane transporters from different organisms. Previously, peptide conjugates have been used to deliver toxic moieties to $C$. albicans via the peptide transport system (Becker \& Naider, 1995). Synthetic analogues of the polyoxins and nikkomycins, which inhibit chitin synthase (Cabib, 1991), have also been designed to enter $C$. albicans through the peptide transport system (Becker \& Naider, 1995). Hence, these studies may facilitate the design of an effective and specific anticandidal drug by exploiting the concept of "illicit transport' (Ames et al., 1973; Fickel \& Gilvarg, 1973; Hammond et al., 1987; Higgins, 1987) in this opportunistic pathogen.

The diploid nature of the $C$. albicans genome and the absence of a known sexual cycle have limited genetic studies with this organism. Nevertheless, significant advances have been made in the past few years towards the genetic manipulation of $C$. albicans. Many $C$. albicans genes have been cloned by functional complementation of $S$. cerevisiae mutants, by nucleotide homology, or by conferring a unique phenotype on the cells (reviewed in Kurtz et al., 1990; Scherer \& Magee, 1990). Here we report the cloning of a $C$. albicans peptide transport gene by functional complementation of a $S$. cerevisiae peptide transport mutant.

\section{METHODS}

Strains, vectors and media. The $S$. cerevisiae strains used in this study were PB1X-9B (MATa ura3-52 leu2-3,112 lys 1-1 bis4-38 ptr2-2), PB3X-5C (MATa ura3-52 lew2-3,112 lys1-1 bis4-38 ptr21), and PB1X-2A (MATa ura3-52 leu2-3,112 lys1-1 bis4-38, PTR2). These strains were constructed as described previously (Perry et al., 1994). C. albicans strain ATCC 18804 (CBS-562) was used for Southern blot analysis.

The genomic $C$. albicans library in the yeast Eschericbia coli shuttle vector YEp24 was kindly provided by Dr Esther Segal, Dept of Human Microbiology, Tel Aviv University, and Dr Zeev Altboum of the Istael Institute for Biological Research. The library was constructed by partial digestion of DNA from C. albicans ATCC 18804 (CBS-562) with BamHI, ligation of 5-15 kb fragments in the tetracycline-resistance gene of YEp24, followed by transformation of E. coli strain HB101 to ampicillin resistance (Altboum et al., 1990).

$C$. albicans and $S$. cerevisiae cells were maintained on YEPD medium containing $(\mathrm{w} / \mathrm{v})$ : peptone $2 \%$; glucose $2 \%$; yeast extract $1 \%$; agar (Difco) $2 \%$. The minimal medium (MM) used for most studies was made by adding $10 \mathrm{ml} 10 \times$ filter-sterilized YNB without amino acids and without ammonium sulfate (Difco), to $90 \mathrm{ml}$ sterile water containing $2 \mathrm{~g}$ glucose, $100 \mathrm{mg}$ allantoin and auxotrophic supplements depending on the strain as follows: histidine $\left(20 \mathrm{mg} \mathrm{l}^{-1}\right)$, uracil $\left(20 \mathrm{mg} \mathrm{l}^{-1}\right)$, lysine $\left(30 \mathrm{mg} \mathrm{l}^{-1}\right.$ ) and leucine (30 $\mathrm{mg} \mathrm{l}^{-1}$ ) (Sherman et al., 1986). Allantoin, a purine catabolite which can serve as the sole nitrogen source for $S$. cerevisiae, was used in MM as it is neutral with respect to peptide transport activity, whereas other nitrogen sources, such as ammonium sulfate and amino acids, affect peptide transport (Basrai et al., 1992; Island et al., 1987). The mutant strain S. cerevisiae PB1X-9B was grown in Complete Medium (CM), which consisted of MM with histidine, uracil, lysine and leucine. S. cerevisiae PB1X-9B transformed with YEp24-based plasmids was grown on CM lacking uracil (CM-Ura) and those transformed with pRS201-based plasmids were grown on CM lacking leucine (CM-Leu) medium. Dipeptide medium [His-Lys, Lys-Met, Lys-Lys, His-Leu, LeuMet, Leu-Leu, or Lys-Leu $(80 \mu \mathrm{M})]$ consisted of MM supplemented with the auxotrophic requirements minus the amino acid components of the added peptides. For example, the dipeptide (Lys-Leu) medium for the growth of $S$. cerevisiae PB1X-9B transformed with the PTR2 gene on a YEp24 plasmid contained MM supplemented with Lys-Leu and histidine. To determine the auxotrophic markers, 'drop-out' plates were made which consisted of MM with all the auxotrophic supplements except the one being tested. E. coli cells used for transformation were grown in LB medium (Sambrook et al., 1989).

Enzymes, chemicals and reagents. L-Leucyl-L- $\left[{ }^{3} \mathrm{H}\right]$ leucine, Ala-Eth and oxalysine-containing peptides were synthesized by standard solution-phase techniques (Becker \& Naider, 1977; Naider et al., 1983) and have been described previously (Basrai et al., 1992; Island et al., 1991). Eth and the dipeptides were obtained from Sigma. Oxalysine, a toxic analogue of lysine, was a gift from Hong-Long Zhang of Shanghai Institute of Materia Medica, Academia Sinica, Shanghai 20021, China. Polyoxin D was purchased from Calbiochem; restriction endonucleases, $\mathrm{T} 4$ DNA ligase, T4 DNA polymerase and alkaline phosphatase were purchased from BRL, New England BioLabs or Promega, and were used according to the manufacturers' specifications.

DNA manipulations. Small-scale plasmid DNA preparations from E. coli transformants were as described in Sambrook $e t$ al. (1989), except that cultures were grown in modified Terrific Broth containing $50 \mu \mathrm{g}$ ampicillin $\mathrm{ml}^{-1}$. Large amounts of plasmid DNA were obtained using the pZ523 column chromatography protocol (5Prime $\rightarrow 3$ Prime, Inc.). Plasmid DNA from $S$. cerevisiae transformants was obtained as described by Sherman et al. (1986). Whole-cell DNA from S. cerevisiae was obtained as described by Ausubel et al. (1990). All agarose gels were prepared in $1 \times$ TAE buffer $(40 \mathrm{mM}$ Tris acetate and $1 \mathrm{mM}$ EDTA, pH 8.0).

E. coli cells were transformed using the Hanahan procedure described in Sambrook et al. (1989). Yeast transformations were done using the procedure described by Gietz et al. (1991) and plates were incubated at $30^{\circ} \mathrm{C}$ for $4 \mathrm{~d}$ or longer.

For Southern analyses whole-cell DNA was digested with restriction enzymes and electrophoresed on $0.9 \%$ agarose gels $\left(1-1.5 \mathrm{~V} \mathrm{~cm}^{-1}\right.$ for 14-18 h). Lambda DNA digested with HindIII was used as a size marker. Southern blotting was done as described in Sambrook et al. (1989). A PCR-amplified 980 bp fragment internal to CaPTR2 (see Fig. 1b) was labelled with $\left[\alpha^{32} \mathrm{P}\right] d C T P$ using the random primer labelling kit from USB to a specific activity of $6-8 \times 10^{8}$ c.p.m. per $\mu$ g DNA. PCRs were carried out according to Innis \& Gelfand (1990) for 35 
cycles with a final $\mathrm{MgCl}_{2}$ concentration of $1 \mathrm{mM}$ with denaturation at $95^{\circ} \mathrm{C}$ for $5 \mathrm{~s}$, annealing at $50^{\circ} \mathrm{C}$ for $5 \mathrm{~s}$, and elongation at $72^{\circ} \mathrm{C}$ for $1 \mathrm{~min}$. Primers used in the PCR reaction were (P15) 5'CCAAAACAGATTCTCCAT3' and (P19) 5'GTTTACAAGCTGCCAGTG3'. The blot containing the probe was incubated for $18 \mathrm{~h}$ at $65^{\circ} \mathrm{C}$ in a rotary oven. The blot was washed twice in $1 \times \mathrm{SSC}$ with $0.1 \% \mathrm{SDS}$ at $55^{\circ} \mathrm{C}$ for $15 \mathrm{~min}$ followed by two washes in $0.1 \times \mathrm{SSC}$ with $0.1 \% \mathrm{SDS}$ at $65^{\circ} \mathrm{C}$ for $15 \mathrm{~min}$. Autoradiography was performed at $-70^{\circ} \mathrm{C}$ in Kodak film holders using Kodak XAR-5 X-Ray film placed between two DuPont Cronex Lighting-Plus intensifying screens.

For plasmid-curing experiments, $S$. cerevisiae transformants were grown nonselectively in YEPD broth for about 40 generations. Cells were then plated on YEPD plates to obtain isolated colonies which were picked, washed with water and resuspended to $1 \times 10^{7}$ cells $\mathrm{ml}^{-1}$. Three microlitres of the cell suspension was spotted as described in growth assays on appropriate media and checked for the auxotrophic markers, sensitivity to ethionine and Ala-Eth, and the ability to grow on dipeptides.

Several subclones were generated from plasmid pMB3 (Fig. 1a) to determine the minimum $C$. albicans DNA fragment that could functionally complement the $S$. cerevisiae ptr 2 mutation (Fig. 1b). Plasmids pMC1, pMC2 and pMC7 were derived from pMB3 by ligation of insert DNA into plasmid pRS201 (Sikorski \& Hieter, 1989). Plasmid pMC1 contained a $3 \cdot 2 \mathrm{~kb}$ HindIII fragment of the insert DNA and pMC2 contained a $2.9 \mathrm{~kb}$ HindIII fragment (with 348 bp of flanking vector DNA). Plasmid pMC7 contained a $2.1 \mathrm{~kb}$ PstI-HindIII fragment from pMB3 ligated to the PstI-HindIII site of pRS201. Plasmids pMC9 and pMC11 contain frameshift mutations at the $B g / \mathrm{II}$ site and $K p n \mathrm{I}$ site, respectively, and were generated by cleavage with the appropriate restriction enzyme, conversion to blunt ends with $\mathrm{T} 4$ DNA polymerase and ligation. Plasmid pMC12 was constructed by deletion of $2.4 \mathrm{~kb}$ NheI-KpnI fragment from pMB3 while plasmid pMC13 was constructed by deletion of the $1.1 \mathrm{~kb}$ MluI-BamHI fragment from pMC12. The constructed plasmids were then used to transform strain PB1X-9B. A two-step selection was done in which transformants were first plated on CM-Leu medium for constructs with LEU2 marker (pRS201) or CM-Ura for constructs with $U R A 3$ marker (YEp24). $\mathrm{LEU}^{+}$ and $\mathrm{URA}^{+}$transformants were then plated on dipeptide medium containing Lys-Leu with other auxotrophic requirements minus the amino acid components of the dipeptide.

The entire $5.1 \mathrm{~kb}$ subclone corresponding to pMC13 that contained CaPTR2 was sequenced. Sequencing was done using the fluorescent dideoxy-terminator method of cycle sequencing on an Applied Biosystems 373A automated DNA sequencer, following the manufacturer's protocols (McCombie et al., 1992; Smith et al., 1986). Both strands were sequenced using primers to fully confirm the order of bases. The DNA sequencing for this analysis was done at the DNA analysis facility of Johns Hopkins University, School of Medicine.

Growth and transport assays. Growth assays to determine the phenotype of the cells was done as described by Island et al. (1991). Briefly, $3 \mu \mathrm{l}$ of culture from a suspension of $1 \times 10^{7}$ cells $\mathrm{ml}^{-1}$ was applied to the surface of the medium and plates were incubated at $30^{\circ} \mathrm{C}$ for $48 \mathrm{~h}$ or longer.

Uptake of L-leucyl-L- $\left[{ }^{3} \mathrm{H}\right]$ leucine was determined as described by Basrai et al. (1992). The final concentration of the components in the uptake assay was: glucose $(2 \%, \mathrm{w} / \mathrm{v}), 4 \mathrm{mM}$ sodium citrate/potassium phosphate buffer ( $\mathrm{pH} 5.5$ ), and L-leucyl-L$\left[{ }^{3} \mathrm{H}\right]$ leucine $\left(10 \mu \mathrm{M} ; 20 \mathrm{mCi} \mathrm{mmol}^{-1} ; 740 \mathrm{MBq} \mathrm{mmol}^{-1}\right)$. Competition experiments were done in the presence of either $1.0 \mathrm{mM}$ L-leucine or $1.0 \mathrm{mM} \mathrm{L}$-leucyl-L-leucine. There was no peptide adsorption to the cell surface or sticking to filters since at $0^{\circ} \mathrm{C}$ the counts were at background level. Each point on the uptake curve represents the mean of three independent determinations whose values did not vary more than $15 \%$ from the mean value. The uptake results, calculated on the basis of $50 \%$ counting efficiency (determined using $\mathrm{L}-\left[{ }^{3} \mathrm{H}\right]$ lysine as a standard, and the specific activity of the peptide), are expressed as nmol peptide uptake per mg cell dry weight.

Sensitivity assays. Sensitivity to ethionine, Ala-Eth, oxalysine and oxalysine-containing peptides was determined as described by Island et al. (1987). Zones of inhibition were measured after $24 \mathrm{~h}$ incubation at $30^{\circ} \mathrm{C}$. Each test comprised at least three independent assays and the results represented in the Tables are means of the values obtained. Maximum variation between the zones of inhibition measured for each test was $\leqslant 2 \mathrm{~mm}$. A value of $7 \mathrm{~mm}$ for the diameter of zone of inhibition represents a minimal growth inhibition value as the disk diameter was $6 \mathrm{~mm}$.

Sensitivity to polyoxin $\mathrm{D}$ was determined using a liquid assay as described by Cabib (1991). Briefly, cells were grown overnight in YNB supplemented with lysine $\left(30 \mathrm{mg} \mathrm{ml}^{-1}\right)$ and leucine $\left(30 \mathrm{mg} \mathrm{m}^{-1}\right.$ ) to a density of approximately $1 \times 10^{7} \mathrm{cells} \mathrm{m}^{-1}$. The cultures were diluted to $1 \times 10^{6}$ cells ml $^{-1}$ in fresh growth medium with or without $750 \mu \mathrm{g}$ polyoxin $\mathrm{D} \mathrm{ml}^{-1}$ and incubated at $30^{\circ} \mathrm{C}$ for $5 \mathrm{~h}$. Appropriate dilutions of the cultures were plated on $\mathrm{CM}-\mathrm{Ura}$ medium, incubated at $30^{\circ} \mathrm{C}$ for $36 \mathrm{~h}$ and colonies were counted.

\section{RESULTS}

\section{Cloning of a C. albicans peptide transport gene}

We screened a $C$. albicans genomic library in YEp24 to determine if the ptr2 mutation in S. cerevisiae could be functionally complemented by a $C$. albicans gene. The host for transformation was the $S$. cerevisiae ptr2-2 mutant, strain PB1X-9B, which is resistant to the toxic dipeptide Ala-Eth, fails to accumulate radiolabelled dileucine at wild-type levels, and is unable to use dipeptides to satisfy its auxotrophic requirement for amino acids. A two-step selection was utilized in which $S$. cerevisiae transformants were first plated to select for uracil prototrophs. The $\mathrm{URA}^{+}$transformants were then plated and scored for the ability to grow on dipeptide medium: MM containing histidine and the dipeptide Lys-Leu in place of the lysine and leucine. This strategy precluded the complementation of the amino acid auxotrophies by homologous $C$. albicans $L Y S$ and $L E U$ genes, and provided strong selective pressure for isolation of peptide transport genes. Histidine in the dipeptide medium served to supplement for the bis4-38 mutation in PB1X-9B and induce the peptide transport system (Basrai et al., 1992; Island et al., 1987). Approximately 15000 S. cerevisiae $\mathrm{URA}^{+}$transformants were obtained after transformation of strain PB1X-9B with $1.5 \mu \mathrm{g}$ DNA from the $C$. albicans library. A portion of each of seven pools, each representing approximately 2200 independent $\mathrm{URA}^{+}$transformants, was plated on dipeptide medium. Several hundred $S$. cerevisiae PTR2 ${ }^{+}$ colonies from each pool were obtained on dipeptide medium after incubation for $3-4 \mathrm{~d}$ at $30^{\circ} \mathrm{C}$. Amino acid requirements of these colonies when checked using 'drop out' plates corresponded to the expected auxotrophies.

Plasmid DNA was isolated from a representative from each of the seven pools of the $S$. cerevisiae PTR2 ${ }^{+}$ 


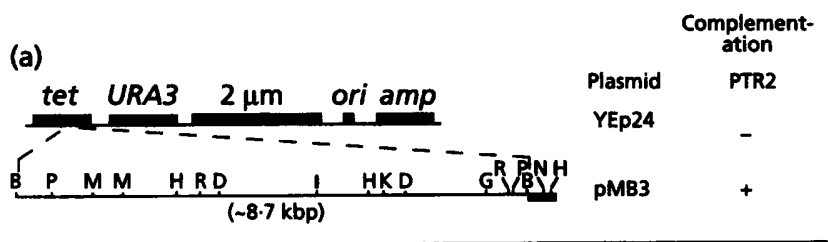

(b)

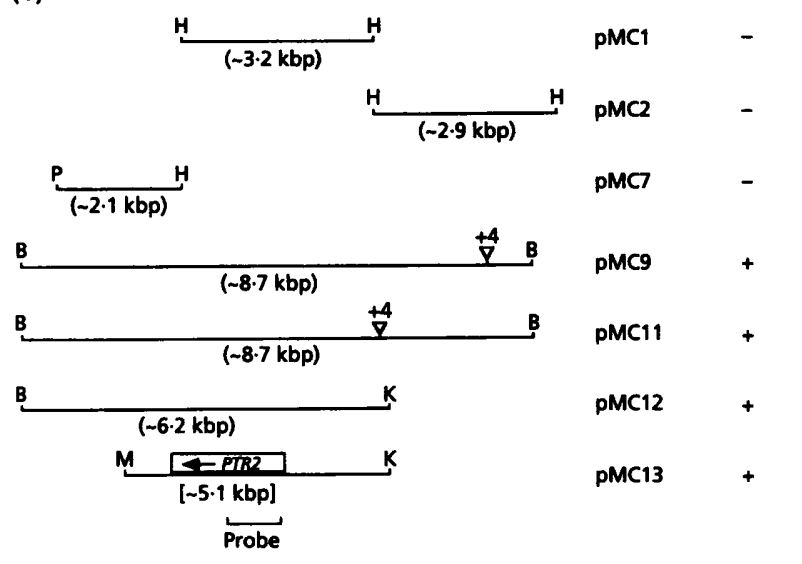

$(\widetilde{1 \mathrm{kbp}})$

Fig. 1. Restriction enzyme map and subcloning of $C$. albicans insert DNA in plasmid pMB3. (a) The restriction sites were mapped by using single and double restriction enzyme digests. The thick line represents the YEp24 vector sequences. The genes tet amp, and ori are derived from plasmid pBR322 which encode for tetracycline resistance, ampicillin resistance and the origin of replication for pBR322, respectively. The URA3 and $2 \mu \mathrm{m}$ are derived from $S$. cerevisiae and encode the URA3 gene, and the $2 \mu \mathrm{m}$ sequence, respectively. Restriction enzymes are abbreviated as B, BamHI; P, Pstl; M, Mlul; H, Hindlll; R, EcoRV; D, Ndel; K, Kpnl; G, Bglll; N, Nhel; I, Hincll. (b) Plasmids containing deletions, subclones or frameshift mutations were derived from plasmid PMB3 as described in Methods, and tested for their ability to complement the $S$. cerevisiae ptr2-2 mutation in strain PB1X-9B. Ability of each plasmid to functionally complement the ptr2-2 mutation is represented as a plus $(+)$ or lack of complementation as a minus (-). Frameshift mutations at the Bg/ll site in plasmid pMC9, and at the Kpnl site in plasmid pMC11, are indicated by a triangle with +4 to denote the frameshift after the site was filled in with Klenow. The PCR-generated probe used in the Southern blots is marked as such.

transformants and was used to transform E. coli HB101. Restriction enzyme analysis of the plasmids from the $E$. coli transformants showed that two different plasmids, pMB3 and pMB5, were isolated, with inserts of $8.7 \mathrm{~kb}$ and $11.2 \mathrm{~kb}$, respectively. A partial restriction enzyme map of the $8.7 \mathrm{~kb}$ insert in plasmid pMB3 was determined (Fig. 1a). The $8.7 \mathrm{~kb}$ insert of pMB3 was also present in plasmid pMB5 (data not shown). Plasmids were amplified and used to transform the mutant strain S. cerevisiae PB1X-9B. Both plasmids, pMB3 and pMB5, were capable of complementing the ptr 2-2 mutation in strain PB1X-9B. It was thus concluded that the $8.7 \mathrm{~kb}$ DNA fragment present in plasmid pMB3 probably contained the entire $C$. albicans CaPTR 2 gene. Deletion and frameshift analyses were used to localize the PTR2 complementing region to a $5 \cdot 1 \mathrm{~kb}$ insert contained in plasmid pMC13 (Fig. 1b).

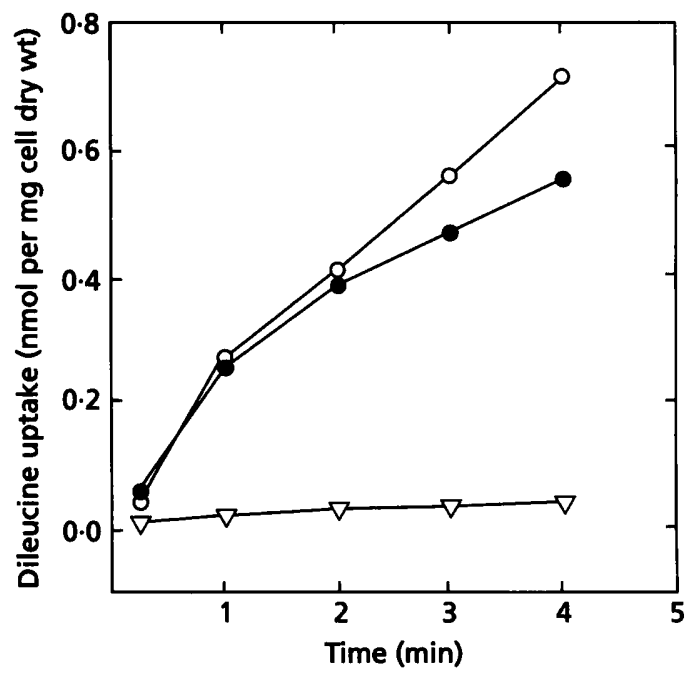

Fig. 2. Transport of L-leucyl-L-[3 H]leucine in $S$. cerevisiae transformants. S. cerevisiae PTR2 gene deletion strain PB1X-2AD transformed with plasmids (YEp24) ( $\nabla)$ or (pMB3) (O), and the wild-type PB1X-2A transformed with (YEp24) (O) grown overnight in $\mathrm{CM}$-Ura medium were harvested in the exponential phase of growth $\left(1-2 \times 10^{7}\right.$ cells $\left.\mathrm{l}^{-1}\right)$, washed and resuspended to $1.5 \times 10^{8}$ cells $\mathrm{ml}^{-1}$ in $2 \%$ glucose. Cell suspension $(500 \mu \mathrm{l})$ was added to an equal volume of reaction mixture containing L-leucyl-L-[ $\left.{ }^{3} \mathrm{H}\right]$ leucine $(10 \mu \mathrm{M}$; specific activity $20 \mathrm{mCi} \mathrm{mmol}^{-1} ; 740 \mathrm{MBq} \mathrm{mmol}^{-1}$ ) as described in Methods. At various time points, $180 \mu \mathrm{l}$ portions were removed, placed on filters and radioactivity was measured by liquid scintillation counting. Each point represents the mean of three values whose values do not vary more than $15 \%$ from the mean value.

Plasmids pMB3 and pMC13 were able to functionally complement the ptr 2 mutation in PB3X-9C, an independently isolated ptr2-1 mutant, and PB1X-2A $\Delta$, a PTR2 deletion strain.

A plasmid-curing experiment showed that the primary $S$. cerevisiae transformants (obtained after transformation with the $C$. albicans library) and secondary $S$. cerevisiae transformants (obtained after transformation with a plasmid isolated from the primary transformants and shuttled through $E$. coli) had lost both the UR $A 3$ marker and the $\mathrm{PTR}^{+}$phenotype. This suggested that the phenotype of the $S$. cerevisiae transformants carrying plasmid pMB3 was due to a plasmid-borne gene and not due to a reversion of the $p t r 2-2$ allele.

\section{Transport of L-leucyl-L-[ $\left[{ }^{3} \mathrm{H}\right]$ leucine in S. cerevisiae transformants}

Neither strain PB1X-9B nor PB1X-2A $\Delta$ accumulated radioactivity from labelled dileucine (Island $e t$ al., 1991, Perry et al., 1994). PB1X-2AL carrying plasmid YEp24 was also unable to transport dileucine (Fig. 2). In contrast, both the wild-type strain PB1X-2A carrying the YEp24 shuttle vector and $\mathrm{PB} 1 \mathrm{X}-2 \mathrm{~A} \Delta$ transformed with $\mathrm{pMB} 3$ showed similar high levels of dipeptide uptake (Fig. 2). The uptake of radioactive dileucine was competed by unlabelled dileucine but not by leucine (data not shown). These results show that $\mathrm{pMB} 3$ restored peptide transport 
Table 1. Sensitivity of S. cerevisiae transformants to ethionine, oxalysine, Ala-Eth and oxalysine-containing peptides

Disk sensitivity assays were done as described in Methods using CM-Ura medium. S. cerevisiae strains PB1X-2A $\triangle(\triangle P T R 2$ :: LEU2) and PB1X-2A (PTR2), which also have other auxotrophic requirements, are described in Methods. The plasmids used to transform the strains are given in parentheses. YEp24 plasmid is a shuttle vector which contains the $S$. cerevisiae $U R A 3$ gene as the selectable marker. pMB3 is plasmid YEp24 containing the CaPTR2 gene.

\begin{tabular}{|c|c|c|c|c|c|c|c|}
\hline \multirow[t]{2}{*}{ Transformant } & \multicolumn{7}{|c|}{ Zone of inhibition (mm)* } \\
\hline & $\mathbf{E}$ & $\mathbf{A E}$ & $\mathbf{0}$ & OG & OLG & $\mathbf{O}(\mathbf{L})_{2} \mathbf{G}$ & $\mathbf{O}(\mathrm{L})_{3} \mathrm{G}$ \\
\hline $\begin{array}{l}\text { PB1X-2A(YEp24) } \\
\text { [PTR2] }\end{array}$ & 50 & 45 & None & 35 & 24 & None & None \\
\hline $\begin{array}{l}\text { PB1X-2A }(\text { YEp24) } \\
{[\triangle P T R 2]}\end{array}$ & 47 & None & None & None & None & None & None \\
\hline $\begin{array}{l}\mathrm{PB} 1 \mathrm{X}-2 \mathrm{~A} \Delta(\mathrm{PMB} 3) \\
{[\Delta P T \mathrm{R} 2]}\end{array}$ & 47 & $41 \dagger$ & None & $20 \dagger$ & $24 \dagger$ & None & None \\
\hline
\end{tabular}

* Ethionine or Ala-Eth $(0.38 \mu \mathrm{mol})$, oxalysine or oxalysine-containing peptides $(0.25 \mu \mathrm{mol})$ were spotted on a disk (diameter $6 \mathrm{~mm}$ ). E, ethionine; AE, Ala-Eth; O, oxalysine; OG, Oxa-Gly; OLG, Oxa-Leu-Gly; $\mathrm{O}(\mathrm{L})_{2} \mathrm{G}$, Oxa-(Leu) ${ }_{2}-\mathrm{Gly} ; \mathrm{O}(\mathrm{L})_{3} \mathrm{G}, \mathrm{Oxa}-(\mathrm{Leu})_{3}-\mathrm{Gly}$. None, no growth inhibition. Each test comprised three independent assays and the results represented in the Table are means of the values obtained. Maximum variation between the zones of inhibition for each test was $\leqslant 2 \mathrm{~mm}$.

$\dagger$ The outline of the zone of inhibition was not very sharp and a hazy zone of inhibition was observed (see Fig. 3).

function to the mutant strain, and that dileucine enters through a transport system distinct from the amino acid permease(s). The initial rate of peptide transport in strain PB1X-2A $\triangle$ (pMB3) was equal to the wild-type level, but the total accumulation was lower upon longer incubation of the cells.

\section{Dipeptides as growth substrates for S. cerevisiae transformants}

Growth assays showed that the mutant strains PB1X-9B (ptr2-2), PB3X-9C (ptr2-1) and PB1X-2A $\Delta(\Delta P T R 2)$ with or without the YEp24 vector were unable to use the dipeptides Lys-Leu, Lys-Met, Lys-Lys, His-Leu, LeuLeu, or His-Lys to satisfy the auxotrophic requirements for amino acids. S. cerevisiae strains PB3X-9C, PB1X-9B or $\mathrm{PB} 1 \mathrm{X}-2 \mathrm{~A} \Delta$ transformed with plasmid $\mathrm{pMB} 3$ were able to use all the dipeptides mentioned above as substrates to satisfy corresponding amino acid auxotrophies in appropriately supplemented media (data not shown). The wild-type strain, PB1X-2A, with or without the vector YEp24, was able to grow on all of the dipeptide substrates tested.

\section{Sensitivity of S. cerevisiae transformants to toxic compounds}

The mutant strain PB1 X-9B is sensitive to the toxic amino analogues ethionine and oxalysine, but is resistant to the toxic peptides Ala-Eth and oxalysine-containing di- and tripeptides (Island et al., 1991; Perry et al., 1994). For disk sensitivity assays, lysine was added to the growth medium to supplement auxotrophic requirements. Lysine reverses the toxicity of oxalysine (Table 1 ) by preventing this amino acid from entering the yeast (Basrai et al., 1992). Disk sensitivity assays showed that the resistance of the deletion mutant PB1X-2A $\Delta$ to Ala-Eth, Oxa-Gly and Oxa-Leu-Gly was reversed by transformation with plasmid pMB3 (Table 1). However, the outlines of the zones of inhibition were not very sharp and growth could be observed close to the boundary of the zone for Ala-Eth (Fig. 3). No toxicity was observed for oxalysine-containing tetra- or pentapeptides toward the $S$. cerevisiae wild-type or any transformant tested. However, $C$. albicans ATCC 18804 exhibited sensitivity to oxalysine-containing di-, tri-, tetra- and pentapeptides (data not shown).

S. cerevisiae $\mathrm{PB} 1 \mathrm{X}-2 \mathrm{~A}(\mathrm{YEp} 24)$ was sensitive $(8 \%$ of cells were viable), whereas $\mathrm{PB} 1 \mathrm{X}-2 \mathrm{~A} \Delta$ (YEp24) was relatively resistant $(80 \%$ of cells viable) to the toxic effect of the peptidyl nucleoside polyoxin $\mathrm{D}\left(750 \mu \mathrm{g} \mathrm{ml}^{-1}\right)$ after a $5 \mathrm{~h}$ incubation. Under similar conditions $S$. cerevisiae PB1X9B(pMB3) showed an intermediate phenotype between the deletion strains and the wild-type strains, as $32 \%$ of the cells were viable after incubation with the drug.

\section{Southern blotting and chromosome mapping of CaPTR2}

Southern blotting was done to establish whether the cloned fragment of DNA originated from $C$. albicans genomic DNA, and to determine if there were other homologous genes in C. albicans. Whole-cell DNA was isolated from C. albicans ATCC 18804 and digested with enzymes (PstI, HindIII, and MluI/HincII) predicted to yield one band on the basis of the restriction map of pMB3 (Fig. 1a). DNA was resolved by electrophoresis, and 

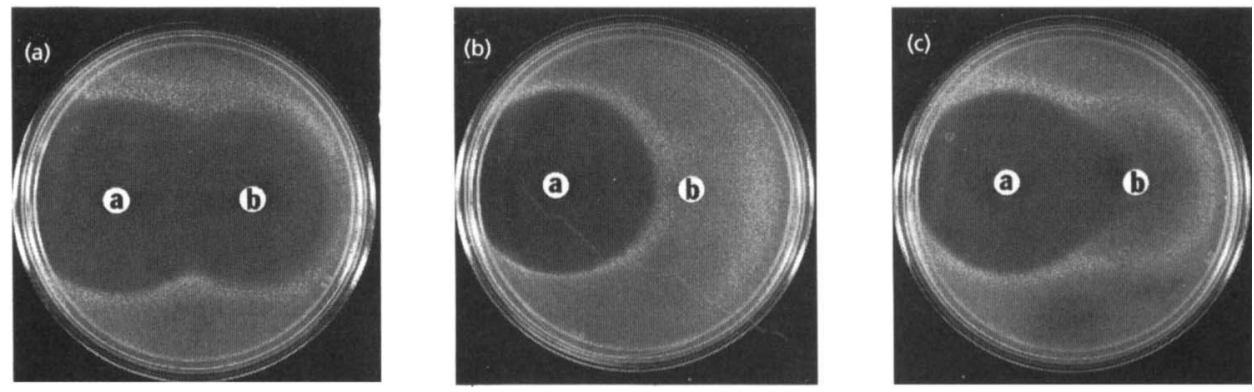

Fig. 3. Sensitivity of S. cerevisiae transformants to Eth and Ala-Eth. Disk sensitivity assays were done in CM-Ura medium as described in Methods. (a) Eth or (b) Ala-Eth (0.38 $\mu$ moles) was applied to disks placed on a lawn of cells. Plate (a), $S$. cerevisiae PB1X-2A(YEp24); plate (b), S. cerevisiae PB1X-2A $\Delta(Y$ E24); plate (c), S. cerevisiae PB1X-2A $\Delta$ (pMB3).

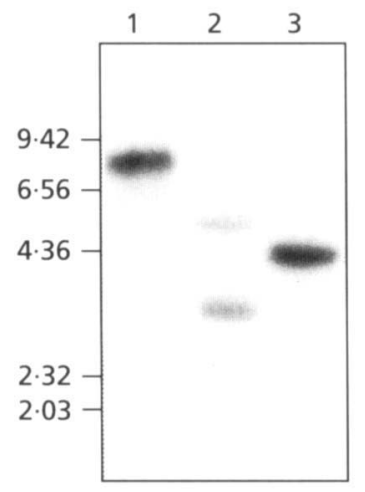

Fig. 4. Southern blots of whole-cell DNA from C. albicans probed with a PCR-amplified C. albicans CaPTR2 internal probe. Whole-cell DNA isolated from C. albicans ATCC 18804 was digested with Pstl (lane 1), HindIII (lane 2) and Mlul/Hincll (lane 3 ), and separated on a $0.9 \%$ agarose gel. The blot was probed with a ${ }^{32}$ P-labelled 980 bp PCR-amplified internal fragment. The location of the probe is indicated in Fig. 1(b).

Southern blotting was done as described in Methods. As seen in Fig. 4, the PCR-derived probe (as described in Fig. 1b) produced the expected bands for all digests $(7.9 \mathrm{~kb}$ for Pst I digests, $3.1 \mathrm{~kb}$ for HindIII digests, and $3.8 \mathrm{~kb}$ for $M l u \mathrm{I} /$ HincII double digests) along with a second band in the HindIII digest $(5.4 \mathrm{~kb})$. The presence of the unexpected band can be explained by multiple copies or restriction fragment length polymorphism (RFLP) within this diploid organism. The CaPTR2 probe did not hybridize to whole-cell DNA from S. cerevisiae under the same stringency conditions (data not shown). The CaPTR2 gene was mapped to chromosome $\mathrm{R}$ that contains the rDNA-containing linkage group (Wickes et al., 1991) by Dr B. B. Magee of University of Minnesota (personal communication; data not shown).

\section{Nucleotide and deduced amino acid sequences of CaPTR2}

The dideoxynucleotide chain-termination method was used to determine the nucleotide sequence of both strands of the complementing region in the plasmid pMC13.
Sequence analysis revealed the presence of ORFs of 488 amino acids (nucleotides 1-1425) and 148 amino acids (nucleotides 1510-1953, Fig. 5) separated by 84 nucleotides. The highly conserved consensus sequences of a type II intron, consisting of a $5^{\prime}$ splice site (GTATGT), a $3^{\prime}$ splice site (TAG), and a branch point (TACTAAC), were identified in the region separating the two ORFs (Rymond \& Rosbash, 1992). The subclone pMC13, which contains both exons and the intron, functionally restored the PTR2 phenotype to mutants, while the subclone, pMC1, which contains the first exon, the intron and 59 nucleotides of the second exon, did not (Fig. 1). Furthermore, exon 2 encodes a peptide of 148 residues which showed $25.5 \%$ identity and $59.1 \%$ similarity to the last 148 amino acids of SacPtr2p, implicating a highly conserved region of the protein that is presumably necessary for function. Therefore, based upon this sequence analysis and subcloning data, we propose that the CaPTR2 gene contains a type II intron spanning 84 nucleotides and separating two ORFs of 475 and 148 amino acid residues (Fig. 5). In contrast, no intron was found in the SacPTR2 gene (Perry et al., 1994).

A search of the GenBank database with the BLAST algorithm (Altshul et al., 1990) showed that three proteins identified as peptide transporters had sequence similarity to CaPtr2p. CaPtr2p exhibited $30 \%$ identity and $56.9 \%$ similarity to SacPtr2p from S. cerevisiae (Perry et al., 1994), $32 \%$ identity and $54.8 \%$ similarity to AtPtr2p from Arabidopsis thaliana (Steiner et al., 1994), and 24.1\% identity and $51.4 \%$ similarity to PepT1p from rabbit intestines (Fei et al., 1994). These sequences were compiled under the Pileup program (Feng \& Doolittle, 1987) of the Genetics Computer Group (GCG) database (Devereux $e t$ al., 1984) and conserved sequences identified (Fig. 6).

\section{DISCUSSION}

The data presented in this paper show that a $C$. albicans gene, CaPTR2, has been cloned which functionally complements $S$. cerevisiae peptide transport mutants of the PTR 2 complementation group. CaPTR 2 complements two independently isolated ptr2 mutants as well as a $S$. cerevisiae strain which is deleted in the PTR2 gene. Due to 
TGATTAATTAACTTAATAGAAAATAGGTCATATTTTTTTTTTTCAACAAATTGTTTGGTTTTTTCATCTMAGTAGA AAATAИAATGAAATCAACTCTTCCAATGAACTCAAGAAAAAMAAATTTAATAAAGGGTMATTGCAMCATAATTECA D

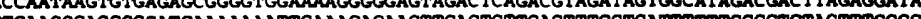
TTGAAGGAGCGGCATCAAAAAAATTGANACACAAGTTGACTGTTGAGTTTGGTGATTTTTTGGGGTCTAGTTTEGGG AATTTCTTATCGCAATTTGTTTTCCACAGTAATTTCACACACCAACAAAAAATTTATTAATCAATPTTACAAACCGGG TACTAAAATCAGACAATCGTTGGAATGATAAACATATTATACACATTTATCCAACATTGCTPTTACTATTTGGACATY ATTTCCAATTAAATCATTATACTTTTTTTAAAAAAACAAAATTGATGCCATATCGCCTCATTAATGTGAAAATATT ATTGTTCTTATTGTTACTTCAGCCTCTTAAGTTTTCTACACTGATTAMTATCACCATTTTGTATTTTATAACCA

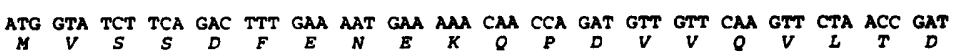



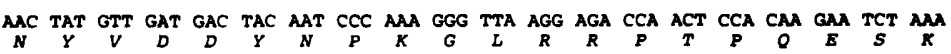
TCT TTG AGA AGA GTT ATT GGT AAC ATA AGA TAC AGT ACA TTT ATG CTT TGT ATT TGT GAA TTT GCT GAA CGT GCT TCA TAT TAT TCT ACC ACT GGT ATT CTT ACT AAT TAT ATT CAA AGA

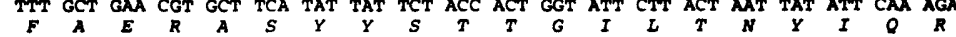

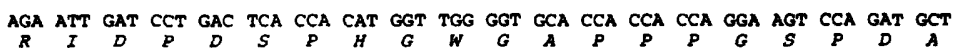

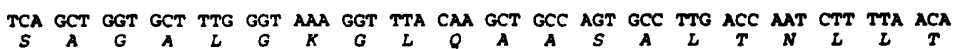
TTT TTA GCT TAT GTA TTC CCT TTA ATT GGT GGT TAT TTA GGT GAT AGC ACA ATT GGA AGA $\begin{array}{llllllllllllllllllll}E & L & A & Y & V & F & P & L & I & G & G & Y & L & G & D & S & T & I & G & R\end{array}$ TGG AAA GCT ATT CAG TGG GGG GTA TTT TTT GGA TTT GTT GCC CAT TTG TTT TTC ATT TTT GCT AGT ATC CCA CAG GCA ATT GAA AAT GCC AAT GCT GGG TTG GGA TTA TGT GTT ATT GCA

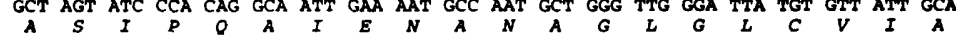

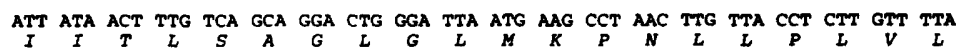

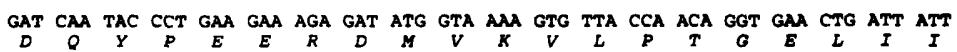
TTG GAT AGA GAG AAA AGT TTG AGT AGA ATC ACA AAC GTA TTT TAT CTT GCA ATT AAT ATT $\begin{array}{llllllllllllllllllll}L & D & R & E & K & S & L & S & R & I & T & N & V & F & Y & L & A & I & N & I\end{array}$ GGT GCC TTT TTG CAA ATT GCT ACT TCG TAT TGT GAA AGA AGA GTT GGG TTT TGG CTT GCA TTC TTT GTT CCT ATG ATA TTG TAC ATA ATT GTA CCA ATT TTC TTA TTT ATT GTG AAA CCT MAA CTT AAG ATT AAG CCA CCA CAA GGT CAA GTC ATG ACC AAT GTC GTC AAG ATT TTA GCA

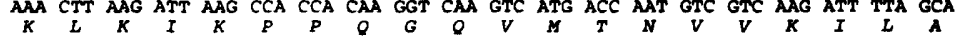

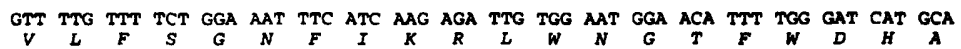
AGA CCT TCA CAT ATG GAA GCC AGA GGG ACT ATT TAC TAC AAT AGT AMA AAG AMA AGT GCC ATT ACT TGG TCT OAC CAA TGG ATA TTA GAT ATC AAG CMA ACA TTT OAT TCC TEC

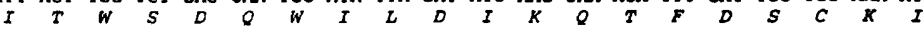
TTT CTT TAC TAT ATT ATT TTC AAT TTG GCC GAT AGT GGA TTA GGA TCA GTA GMA ACT TCC TTA ATT GGT GCT ATG AAA TTA GAC GGA GTT CCA AAT GAT CTT TTT AAT AAT TTT AAT CCA TTG ACC ATT ATC ATT TTG ATT CCG ATC CTT GAA TAC GGA CTC TAC CCA TTG TTG AAC AMA

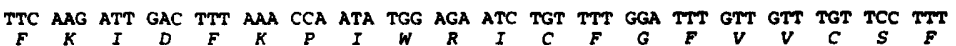

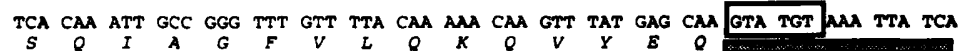
GAG GTT TTT TTT ACA CTC ATt GTA TAG TTC TTT TCA AGA TTC CGT TGA PA CTA AC TCC D.

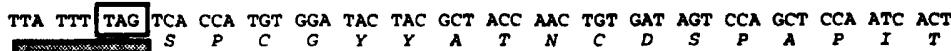
GCC TGG AAA GCT TCA TCT CTT TTC ATA TTA GCC GCC GCT GGT GAA TGT TGG GCT TAT ACC ACT GCT TAT GAA TTG GCA TAT ACC AGA TCA

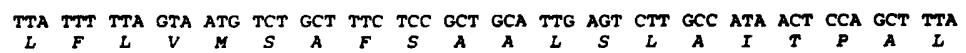
aAA GAC CCT AAT TTA CAT TGG GTA TTC CTT GCA ATT GGT CTT GCT GGA TTC CTT TGT GCC

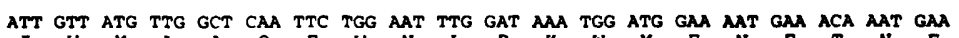
AGA GAA AGA TTG GAT AGA GAA GAA GAA GAG GAA GCC AAC AGA GGA ATC CAC GAT GTT GAT CAT CCA ATT GAA GCA ATT GTA TCT ATC AAG TCA TGA TTATATATTTATATatalatTacatractC

TTTCGAATTAATGACATTTGCAAACATACATCTTATCTCTAATTAGTTTATGTGAMAATAATCTAGTATAOTCTGCT

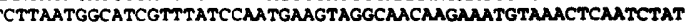
CTGACAATTTATCTTTAAAAAAATGCTTT T2ATTAAATCAAATTCAAAAATGCCAACCATTTTTAGTGTCTGCTATAG TCTATAAAGTTGTTAATAACGATCATTTC TTTTTATTACCCTTITTCGATGCTGGTTTCTTATTATTTGATTTTCCACT TTTATTGCTGTCACCAGAACCACCTGGCANACTAATTTAACTTTTCCAACAGTGAAATACCAACAATATCATTTGTT
Fig. 5. Nucleotide sequence and predicted amino acid sequence of CaPTR2. The putative amino acids encoded by the ORF are numbered on the left and the nucleotides are numbered on the right. The intron is indicated by the shaded underline with the consensus $5^{\prime}$ splice site, $3^{\prime}$ splice site and branch point of the intron enclosed within boxes. The sequence shown represents 2461 nucleotides of the 5161 that were sequenced. The full sequence has been assigned the GenBank accession number u09781. 




Fig. 6. A GenBank comparison using the GCG program Pileup was done for the peptide transport proteins Ptr2p of $C$. albicans, $S$. cerevisiae and $A$. thaliana along with the PepT1p from rabbit intestine. Conserved residues are denoted as 'consensus'. the fact that CaPtr2p shows high similarity to SacPtr2p and contains multiple hydrophobic domains typical of transporter proteins (Grenson, 1992; Higgins, 1992), we propose that $\mathrm{CaPtr} 2 \mathrm{p}$ is a membrane-bound structural component of peptide transport in C. albicans. However, CaPTR2 did not fully restore peptide transport activity to $S$. cerevisiae mutants. As seen in Fig. 2, the level of accumulation of radiolabelled dipeptide in $S$. cerevisiae PB1X-2A $(\mathrm{pMB} 3)$ was somewhat lower than in the wildtype strain $S$. cerevisiae $\mathrm{PB} 1 \mathrm{X}-2 \mathrm{~A}(\mathrm{YEp} 24)$. We also observed that transformants with the plasmid pMB3 showed decreased sensitivity to Ala-Eth, Oxa-Gly, OxaLeu-Gly and polyoxin $\mathrm{D}$ when compared to transformants with SacPTR2 (data not shown). Interestingly, the $8.7 \mathrm{~kb}$ fragment from pMB3 did not complement ptr 2 mutants when expressed on a low-copy-number plasmid (data not shown). These results indicate either a sub-optimal expression of CaPTR2 in the heterologous system, or different structural specificities of the proteins encoded by the CaPTR2 gene as compared to the $S$. cerevisiae PTR2 gene. Several $C$. albicans genes, such as ERG16 and ERG7, are reported to be expressed poorly in S. cerevisiae (Kelly et al., 1990; Kirsch et al., 1988). Additionally, it is possible that the product encoded by CaPTR2 is unable to interact efficiently with other requisite components of the $S$. cerevisiae peptide transport system to restore full peptide transport activity. This hypothesis is based on studies with $S$. cerevisiae in which at least three genes, PTR1, PTR2 and PTR3, are involved in peptide transport. A mutation in either PTR1 or PTR2 renders the cells totally incapable of peptide transport (Island $e t$ al., 1991). The mechanistic role of Prt1p in peptide transport at this point is not fully understood but is postulated to be involved in regulation of PTR2 expression (Alagramam et al., 1995).

Southern blot analyses demonstrated each of the predicted bands as well as an additional band in the HindIII digest. The unexpected band can be explained by RFLP between the two chromosomal homologues or alternatively by multiple copies of $C a P T R 2$ on the $\mathrm{R}$ chromosome. We favour the former explanation because all other digests produced their respective single bands. Both $M l u \mathrm{I}$ and $P_{s t \mathrm{I}}$ restriction sites reside well outside the ORF and we believe it unlikely that two enzymes would produce the same band in multiple copies of a gene. RFLP has been demonstrated previously at the EXG1 (Chambers et al., 1993) and $U R A 3$ loci (Kelly et al., 1987) in C. albicans.

The nucleotide sequence from pMC13 predicts a protein of 623 amino acids with a molecular mass of $70 \mathrm{kDa}$ and a $\mathrm{pI}$ of 6.4 . Computer-assisted analysis of the structure revealed an amino terminus of 63 hydrophilic residues followed by 12 hydrophobic segments of approximately 20 amino acids in length, with intervening hydrophilic segments and a carboxy terminus consisting of 43 hydrophilic residues. An almost identical hydropathy plot was seen in peptide transporters in $S$. cerevisiae and $A$. thaliana (Steiner et al., 1994). Furthermore, computerassisted predictions of protein secondary structure revealed that the hydrophobic regions (putative transmembrane domains) consisted of $\beta$-sheet-forming regions 
rather than $\alpha$-helices. Predicted $\beta$-sheet formation in membrane proteins has been reported previously in the $S$. cerevisiae proteins Ptr2p (Perry et al., 1994) and Dal5p, an allantoin permease (Rai et al., 1988).

The existence of multiple peptide permeases based on growth and toxicity studies has been reported previously in C. albicans (Becker \& Naider, 1995; McCarthy et al., 1985; Payne et al., 1991), while S. cerevisiae has been shown by genetic experiments to possess only a di-tripeptide transporter (Perry et al., 1994). The fact that PB1X-9B transformed with pMB3 is resistant to oxalysine-containing tetra- and pentapeptides, whereas the wild-type $C$. albicans 18804 is sensitive to toxic tetra- and pentapeptides, suggests that $\mathrm{CaPtr} 2 \mathrm{p}$ is only capable of transporting diand tripeptides, although a size limitation may be imposed on $\mathrm{CaPtr} 2 \mathrm{p}$ due to its expression in the $S$. cerevisiae heterologous host. Therefore, more genetic studies must be undertaken to determine whether multiple $C$. albicans peptide transport genes exist. Cloning of a $C$. albicans oligopeptide transporter gene by functional expression in $S$. cerevisiae is currently being attempted in our laboratory.

A BLAST search identified significant similarity between CaPtr2p and the peptide transporters SacPtr2p of $S$. cerevisiae, AtPtr2p of $A$. thaliana, and PepT1p of rabbit intestine (Fig. 6). In contrast, neither the S. cerevisiae STE6 gene, which exports the peptide mating pheromone afactor from MATa cells (Kuchler et al., 1989; McGrath \& Varshavsky, 1989), nor the OPP operon of Salmonella typhimurium (Hiles et al., 1987), which encodes the peptide transport system of enteric bacteria, hybridized to $C$. albicans DNA as determined by Southern blotting (data not shown). Furthermore, a BLAST search revealed no similarity between $\mathrm{CaPtr} 2 \mathrm{p}$ and a $C$. albicans multipledrug-resistance protein product containing 12 transmembrane domains (Ben-Yaacov et al., 1994). This analysis has led us to the identification of a new family of predominately eukaryotic peptide transporters (Steiner $e t$ al., 1994).

In summary, we report here the identification, cloning, and sequencing of a $C$. albicans gene that can functionally complement a $S$. cerevisiae peptide transport mutant. We have demonstrated that $S$. cerevisiae is a model recipient for peptide transporters and could provide an invaluable tool to evaluate peptide transport in other fungi and from complex organs, such as the intestine and the kidney, under controlled conditions. Such studies should prove invaluable in the rational design of peptide-based drugs.

\section{ACKNOWLEDGEMENTS}

This work was supported by a grant from the American Cancer Society, BE-39B. We gratefully acknowledge Dr Beatrice Magee of the University of Minnesota for chromosomal mapping of the CaPTR2 gene, Dr Esther Segal and Dr Zeev Altboum for providing the $C$. albicans genomic library, Roxanne Ingersoll for sequencing, and Kim Caldwell for helping with the Southern blotting. We thank Larry Zhang for peptide synthesis, Michael Craig and Keith Henry for technical assistance, and Stevan Marcus, Guy Caldwell, Henry-York Steiner, David Barnes and Kumar Alagramam for helpful suggestions.

\section{REFERENCES}

Alagramam, K., Naider, F. \& Becker, J. M. (1995). A recognition component of the ubiquitin system is required for peptide transport in Saccharomyces cerevisiae. Mol Microbiol 15, 225-234.

Altboum, Z., Gottlieb, S., Lebens, G. A., Polacheck, I. \& Segal, E. (1990). Isolation of the Candida albicans histidinol dehydrogenase (HIS4) gene and characterization of a histidine auxotroph. $J$ Bacteriol 172, 3898-3904.

Altshul, S. F., Gish, W., Miller, W., Myers, E. W. \& Lipman, D. J. (1990). Basic local alignment search tool. J Mol Biol 215, 403-410.

Ames, B. N., Ferro-Luzzi Ames, G., Young, J. D., Tsuchiya, D. \& Lecocq, J. (1973). Illicit transport: the oligopeptide permease. Proc Natl Acad Sci USA 70, 456-458.

Ausubel, F. M., Brent, R., Kingston, R., Moore, D. D., Seidman, J. G., Smith, J. A. \& Struhl, K. (1990). Current Protocols in Molecular Biology 2. New York: Wiley Interscience.

Bartel, B., Wunning, I. \& Varshavsky, A. (1990). The recognition component of the N-end rule pathway. EMBO J 9, 3179-3189.

Basrai, M. A., Zhang, H.-L, Miller, D., Naider, F. \& Becker, J. M. (1992). Toxicity of oxalysine and oxalysine-containing peptides against Candida albicans: regulation of peptide transport by amino acids. J Gen Microbiol 138, 2353-2362.

Becker, J. M. \& Naider, F. (1977). Peptide transport in yeast: uptake of radioactive trimethionine in Saccharomyces cerevisiae. Arch Biochem Biophys 178, 245-255.

Becker, J. M. \& Naider, F. (1980). Transport and utilization of peptides by yeast. In Transport and Utilization of Amino Acids, Peptides and Proteins by Microorganisms, pp. 257-279. Edited by J. W. Payne. London: John Wiley.

Becker, J. M. \& Naider, F. (1995). Fungal peptide transport as a drug delivery system. In Peptide Based Drug Design: Controlling Transport and Metabolism, pp. 369-384. Edited by M. Taylor \& G. Amidon. Washington, DC: American Chemical Society.

Ben-Yaacov, R., Knoller, S., Caldwell, G. A., Becker, J. M. \& Koltin, Y. (1994). Candida albicans gene encoding resistance to benomyl and methotrexate is a multidrug resistance gene. Antimicrob Agents Chemotber 38, 648-652.

Cabib, E. (1991). Differential inhibition of chitin synthetases 1 and 2 from Saccharomyces cerevisiae by polyoxin D and nikkomycins. Antimicrob Agents Cbemother 35, 170-173.

Chambers, R. S., Broughton, M. J., Cannon, R. D., Carne, A., Emerson, G. W. \& Sullivan, P. A. (1993). An exo- $\beta-(1,3)$-glucanase of Candida albicans: purification of the enzyme and molecular cloning of the gene. J Gen Microbiol 139, 325-334.

Devereux, J., Haeberli, P. \& Smithies, O. (1984). A comprehensive set of sequence analysis programs for the VAX. Nucleic Acids Res 12, 387-395.

Fei, Y.-J., Kanai, Y., Nussberger, S., Ganapathy, V., Leibach, F. H., Romero, M. F., Singh, S. K., Boron, W. F. \& Hediger, M. A. (1994). Expression cloning of a mammalian proton-coupled oligopeptide transporter. Nature 368, 563-566.

Feng, D.-F. \& Doolittle, R. F. (1987). Progressive sequence alignment as a prerequisite to correct phylogenetic trees. $J$ Mol Evol 25, 351-360.

Fickel, T. E. \& Gilvarg, C. (1973). Transport of impermeant substances in Escberichia coli by way of oligopeptide permease. Nature 241, 161-163.

Gietz, D., Andrew, J., Woods, R. \& Schiestl, R. (1991). Improved methods for high efficiency transformation of intact yeast cells. Nucleic Acids Res 20, 1425.

Grenson, M. (1992). Amino acid transporters in yeast: structure, 
function and regulation. In Molecular Aspects of Transport Proteins, pp. 219-245. Edited by J. J. H. H. M. De Pont. Amsterdam: Elsevier.

Hammond, S. M., Claesson, A., Jansson, A. M., Larsson, L.-G., Pring, B. G., Town, C. M. \& Ekstrom, B. (1987). A new class of synthetic antibacterials acting on lipopolysaccharide biosynthesis. Nature 327, 730-732.

Higgins, C. F. (1987). Synthesizing designer drugs. Nature 327, 655-656.

Higgins, C. F. (1992). ABC transporters: from microorganisms to man. Annu Rev Cell Biol 8, 67-113.

Hiles, I. D., Gallagher, M. P., Jamieson, D. J. \& Higgins, C. F. (1987). Molecular characterization of the oligopeptide permease of Salmonella typhimurium. J Mol Biol 195, 125-142.

Innis, M. A. \& Gelfand, D. H. (1990). Optimizations of PCR. In PCR Protocols: a Guide to Methods and Applications, pp. 3-12. Edited by M. A. Innis, D. H. Gelfald, J. J. Sninsky and T. J. White. New York: Academic Press.

Island, M. D., Naider, F. \& Becker, J. M. (1987). Regulation of dipeptide transport in Saccharomyces cerevisiae by micromolar amino acid concentrations. $J$ Bacteriol 169, 2132-2136.

Island, M. D., Perry, J. R., Naider, F. \& Becker, J. M. (1991). Isolation and characterization of $S$. cerevisiae mutants deficient in amino acid-inducible peptide transport. Curr Genetics 20, 457-463.

Kelly, R., Miller, S. M., Kurtz, M. B. \& Kirsch, D. R. (1987). Directed mutagenesis in Candida albicans: one step gene disruption to isolate UR A3 mutants. Mol Cell Biol 7, 199-207.

Kelly, R., Miller, S. M., Lai, M. H. \& Kirsch, D. R. (1990). Cloning and characterization of the 2,3-oxidosqualene cyclase-encoding gene of Candida albicans. Gene 87, 177-183.

Kirsch, D. R., Lai, M. H. \& O'Sullivan, J. (1988). Isolation of the gene for cytochrome P450 L1A1 (lanosterol 14 alpha-demethylase) from Candida albicans. Gene 68, 229-237.

Kuchler, K., Sterne, R. E. \& Thorner, J. (1989). Saccharomyces cerevisiae STE6 gene product: a novel pathway for protein export in eukaryotic cells. EMBO J 8, 3973-3984.

Kurtz, M. B., Kelly, R. \& Kirsch, D. R. (1990). Molecular genetics of Candida albicans. In The Genetics of Candida, pp. 21-73. Edited by D. R. Kirsch, R. Kelly \& M. B. Kurtz. Boca Raton, FL: CRC Press.

McCarthy, J. P., Nisbet, L. J., Boehm, J. C. \& Kingsbury, W. D. (1985). Multiplicity of peptide permeases in Candida albicans: evidence from novel chromophoric peptides. $J$ Bacteriol 162, 1024-1029.

McCombie, W. R., Heiner, C., Kelley, J. M., Fitzgerald, M. G. \& Gocayne, J. D. (1992). Rapid and reliable fluorescent cycle sequencing of double stranded templates. DNA Seq 2, 289-296.

McGrath, J. P. \& Varshavsky, A. (1989). The yeast STE6 gene encodes a homologue of the mammalian multidrug resistance Pglycoprotein. Nature 340, 400-404.
Matthews, D. M. (1991). Protein Absorption: Development and Present State of the Subject. New York: Wiley-Liss.

Naider, F. \& Becker, J. M. (1987). Peptide transport in Candida albicans: implications for the development of antifungal agents. Curr Top Med Mycol 2, 170-198.

Naider, F., Shenbagamurthi, P., Steinfeld, A. S., Smith, H. A., Boney, C. \& Becker, J. M. (1983). Synthesis and biological activity of tripeptidyl polyoxins as antifungal agents. Antimicrob Agents Chemother 24, 787-796.

Payne, J. W. (1980). Transport and utilization of peptides by bacteria. In Microorganisms and Nitrogen Sources, pp. 211-256. Edited by J. W. Payne. New York: John Wiley.

Payne, J. W., Barrett-Bee, K. J. \& Shallow, D. A. (1991). Peptide substrates rapidly modulate expression of dipeptide and oligopeptide permeases in Candida albicans. FEMS Microbiol Lett 79, 15-20.

Perry, J. R., Basrai, M. A., Steiner, H.-Y., Naider, F. \& Becker, J. M. (1994). Isolation and characterization of a Saccharomyces cerevisiae peptide transport gene. Mol Cell Biol 14, 104-115.

Rai, R., Genbauffe, F. S. \& Cooper, T. G. (1988). Structure and transcription of the allonantoate permease gene (DAL5) from Saccharomyces cerevisiae. J Bacteriol 170, 266-271.

Rymond, B. C. \& Rosbash, M. (1992). Yeast pre-mRNA splicing. In The Molecular and Cellular Biology of the Yeast Saccharomyces, pp. 143-192. Edited by E. W. Jones, J. R. Pringle \& J. R. Broach. Cold Spring Harbor, NY: Cold Spring Harbor Laboratory.

Sambrook, J., Fritsch, E. F. \& Maniatis, T. (1989). Molecular Cloning: a Laboratory Manual, 2nd edn. Cold Spring Harbor, NY: Cold Spring Harbor Laboratory.

Scherer, S. \& Magee, P. T. (1990). Genetics of Candida albicans. Microbiol Rev 54, 226-241.

Sherman, F., Fink, G. R. \& Hicks, J. B. (1986). Methods of Yeast Genetics. Cold Spring Harbor, NY: Cold Spring Harbor Laboratory.

Sikorski, R. S. \& Hieter, P. H. (1989). A system of shuttle vectors and yeast host strains designed for efficient manipulation of DNA in Saccharomyces cerevisiae. Genetics 122, 19-27.

Smith, L. M., Sander, J. Z., Kaiser, R. J., Hughes, P., Dodd, C., Connel, C. R., Heiner, C., Kent, S. B. \& Hood, L. E. (1986). Fluorescence detection in automated DNA sequence analysis. Nature 321, 674-679.

Steiner, H.-Y., Song, W., Naider, F., Zhang, L., Stacey, G. \& Becker, J. M. (1994). An Arabidopsis peptide transporter is a member of a new class of membrane transport proteins. Plant Cell 6, 1289-1299.

Wickes, B., Staudinger, J., Magee, B. B., Kwon-Chung, K. J., Magee, P. T. \& Scherer, S. (1991). Physical and genetic mapping of Candida albicans: several genes previously assigned to chromosome 1 map to chromosome $\mathrm{R}$, the rDNA containing linkage group. Infect Immun 59, 2480-2484.

Received 14 October 1994; accepted 12 January 1995. 